\title{
Design and Dynamic Modelling of a Hybrid Power System for a House in Nigeria
}

\author{
Lawrence O. Aghenta $(\mathbb{D})$ and $M$. Tariq Iqbal \\ Electrical and Computer Engineering Department, Faculty of Engineering and Applied Science, Memorial University \\ of Newfoundland, St. John's, NL, Canada \\ Correspondence should be addressed to Lawrence O. Aghenta; loaghenta@mun.ca
}

Received 26 October 2018; Revised 27 December 2018; Accepted 19 January 2019; Published 30 April 2019

Guest Editor: Paolo Conti

Copyright @ 2019 Lawrence O. Aghenta and M. Tariq Iqbal. This is an open access article distributed under the Creative Commons Attribution License, which permits unrestricted use, distribution, and reproduction in any medium, provided the original work is properly cited.

\begin{abstract}
This paper presents the design and dynamic modelling of a hybrid power system for a house in Nigeria. Thermal modelling of the house under consideration is carried out using BEopt software to accurately study the heat loss through the walls, windows, doors, and roof of the house. The analysis of this thermal model is used to determine hourly load data. Design of an optimum hybrid power system for the house is done with HOMER Pro software. The hybrid power system is made up of a diesel generator and a stand-alone PV system. The proposed PV system consists of PV arrays, DC-DC boost converter, MPPT controller, singlephase full-bridge inverter, inverter voltage mode controller (PI controller), and single-phase step-up transformer. Dynamic simulation of the proposed PV system component of the hybrid power system is carried out in MATLAB/Simulink environment to study the power quality, harmonics, load impact, voltage transients, etc. of the system, and the simulation results are presented in the paper.
\end{abstract}

\section{Introduction}

Electricity is one of the basic amenities of man because of its wide usage in various aspects of life. Thus, the need for a reliable source of power supply cannot be over emphasized. Unfortunately, electrical power supply in developing countries like Nigeria is unreliable, thereby making life difficult. Nigeria is a federal republic in West Africa, bordering Benin in the west, Chad and Cameroon in the east, and Niger in the north. Its coast in the south lies on the Gulf of Guinea in the Atlantic Ocean. It comprises 36 states and the Federal Capital Territory, where the capital, Abuja, is located [1]. Nigeria is often referred to as the "Giant of Africa," owing to its large population and economy. With 186 million inhabitants, Nigeria is the most populous country in Africa and the seventh most populous country in the world [1]. Nigeria is the 12th largest producer of petroleum in the world, and the 8th largest exporter, and has the 10th largest proven reserves. Apart from petroleum, Nigeria is also blessed with other natural resources including natural gas, tin, iron ore, coal, limestone, niobium, lead, zinc, and arable land. Despite these abundant natural resources, the country is unable to generate enough electricity to support the national population. Presently, the amount of generated power is about 9 percent of the required power needed to completely electrify the country (about $80,000 \mathrm{MW}$ capacity is required but barely $7,445 \mathrm{MW}$ is installed) [2]; thus, the country continues to experience extreme electricity shortage and prolonged periods of power outages such that a typical Nigerian household has electric power supply for 5 hours a day on the average. Over the years, households have had to rely mostly on private power generators to meet their electricity needs. However, the growing price of petroleum products to power these generators is a major concern for the average household. Also, the noise and fumes from these generators are having significant impacts on the environment as the fumes continue to contribute to the carbon footprints of the houses. To avoid these negative environmental impacts of fossil fuel usage, it is important to find ways to economically utilize clean and sustainable sources of energy such as wind and solar energies to meet the electricity needs of the house. Various literatures presented in [3] have reported abundant 
solar resource potential of between $3.5 \mathrm{kWh} / \mathrm{m}^{2} /$ day and $7.0 \mathrm{kWh} / \mathrm{m}^{2} /$ day across Nigeria and average sunshine duration of 6.25 hours per day. This is corroborated by the April 2018 weekly agrometeorological data for the dekad bulletin of the Nigerian Meteorological Agency (NiMet) [4], which shows an average solar irradiation for a northern city like Zaria to be $23.4 \mathrm{MJ} / \mathrm{m}^{2} /$ day $\left(6.5 \mathrm{kWh} / \mathrm{m}^{2} /\right.$ day $)$ and that for a southern city like Benin City to be $17.3 \mathrm{MJ} / \mathrm{m}^{2} /$ day $\left(4.81 \mathrm{kWh} / \mathrm{m}^{2} /\right.$ day). Despite these large solar resources, Nigeria is yet to fully integrate solar energy into its energy generation mix.

\section{Literature Review}

Individuals and researchers across Nigeria have over the years taken advantage of the availability of abundant solar resources and its ease of use to design photovoltaic (PV) systems to meet their private energy needs. Udoakah et al. [5] designed a $1 \mathrm{kVA}$ PV system for electrical laboratory in the Faculty of Engineering at the University of Uyo to solve the problem of sudden power failures during laboratory sessions. The major components of their off-grid PV system design include two $150 \mathrm{~W}$ solar panels connected in parallel (PV module), an inverter unit, one $12 \mathrm{~V}$, $100 \mathrm{AH}$ deep cycle battery, charge controller unit, and an automatic control unit to automatically switch from the inverter to the public power supply whenever the public power was available and vice versa. Elsewhere, Okoye et al. [3] proposed a stand-alone solar PV system design solution and cost model analysis using both intuitive and numerical methods. The authors considered constant electrical load demands of a house each in three different major cities in Nigeria: Onitsha, located in the southeast region; Kano, located in northwest region; and Lagos, located in the southwest region as case studies using the 2016 meteorological solar radiation data sets for these cities in their analysis. In their solution, they used intuitive and numerical methods to calculate the required PV area and capacity, the number of PV modules, the corresponding capacities of the battery, the inverter, and the charge controller while using the life cycle cost analysis model to investigate the optimal cost solution for the PV system design which takes into account the initial capital investment, the present cost of the battery, the inverter, the charge controller, and the balance of system cost to estimate the net present value of the PV system as well as the estimated future value of the system using appropriate discount rates for each of the components of the PV system. Akinyele and Rayudu [6] proposed an off-grid PV system design solution to solve electrical power problems in two rural households in Nigeria using HOMER software for the modelling and analysis of the PV system and cost. In their research, they considered energy consumption scenarios of two households in Agwandodo settlement in Gwagwalada, Abuja, with moderate loads. Considering the average loads and operating hours of the domestic appliances for each of these houses, they used both MATLAB and HOMER tools to obtain the daily load profiles for the two houses. They then used HOMER software to obtain the optimized component sizes of the stand-alone PV systems for the houses and costs.

In yet another development, Adaramola et al. [7] presented the feasibility analysis of hybrid PV solar-diesel power system application for the remote areas in the northern part of Nigeria using Jos and its environs in Plateau State as a case study. In their solution, electrical energy of $1.5 \mathrm{MWh}$ per day with daily peak load of $236 \mathrm{~kW}$ was simulated for rural areas with a population of about 1,500 households and with the assumption that each household consumed $1 \mathrm{kWh}$ of energy per day. The values were then used to determine the ratings of the other components of the proposed hybrid PV solardiesel system including PV modules, diesel generator, battery, and power converter.

In most of the above mentioned papers, the energy requirements for their hybrid/PV system design have been estimated by calculating the power requirement of each device in the house and estimating the approximate number of hours each device would utilize power in a day. The problem with this method of estimating energy needs for PV system design is that it does not consider the type and size of the locations of electrical appliances, the building materials, orientation and dimensions of the house, and heat loss through the walls, windows, doors, and roofs of the house. Also, the intuitive and numerical methods of estimating energy requirements presented in the other papers above have some drawbacks. Although the intuitive methodology is relatively simple to compute compared to the numerical method, it has the drawback of often over sizing or under sizing the entire system due to not modelling the interactions among the subsystem components [3]. The numerical method, on the other hand, is a complex solution prone to errors as it involves a lot of parameter estimations.

In this paper, the enumerated shortcomings above are addressed in designing a hybrid power system. This paper involves three major tasks. Firstly, a detailed thermal modelling of the chosen house using BEopt software is completed. Secondly, optimum hybrid power system design using HOMER Pro software is presented. Finally, MATLAB/Simulink dynamic simulation of the optimum PV system component of the proposed hybrid power system is presented along with the simulation results. Specifically, the contributions of this study include the following:

(i) Thermal modelling of the house, taking into account important parameters such as the type and size of the house, location and orientation of the house, materials used in building the house, number and types of appliances in the house, and number of occupants, as well as heat loss through the walls and windows. Such modelling resulted in a detailed hourly and annual load profile of the house. This, to the best of the authors' knowledge from reviewed literatures, has never been done for the determination of load profiles in that region

(ii) Determination of the optimal renewable energy mix and conventional diesel generator size of the hybrid power system for the specific house in Nigeria 


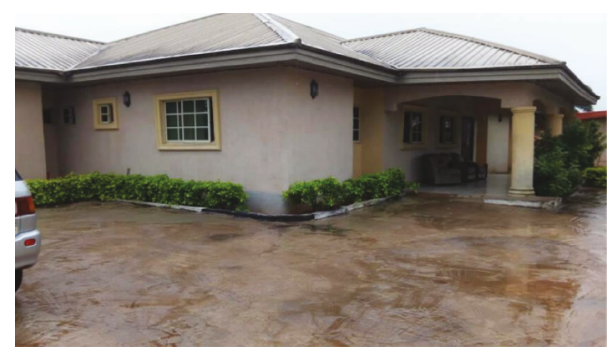

FIGURE 1: House side view.

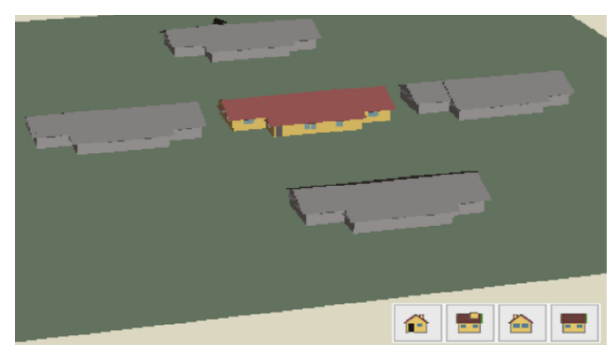

Figure 2: BEopt software house design.

(iii) Assessment of the optimal system configuration to achieve energy independence for the house

(iv) MATLAB/Simulink dynamic simulation of the PV system component of the proposed hybrid power system to study the power quality, harmonics, load impact, and voltage transients under various conditions specific to the house under consideration

\section{Thermal Modelling of the House in BEopt}

In order to design a hybrid power system for a household, it is important to accurately determine the energy needs of the household for which the system is being designed. This can be achieved through thermal modelling of the house [8]. Building energy optimization (BEopt) software, developed by the National Renewable Energy Laboratory, provides capabilities to evaluate residential building designs and identify cost-optimal solution at various levels of whole-house energy savings along the path to zero net energy $[8,9]$. It provides detailed simulation-based analysis based on specific house characteristics, such as size, architecture, occupancy, vintage, location, and utility rates. BEopt can be used to analyze both new construction and existing home retrofits, as well as single-family detached and multifamily buildings, through evaluation of single building designs, parametric sweeps, and cost-based optimizations [9]. The chosen house is located in Benin City (latitude $6^{\circ} 20^{\prime} 0^{\prime \prime} \mathrm{N}$ and longitude $\left.5^{\circ} 38^{\prime} 0^{\prime \prime} \mathrm{E}\right)$, Edo State, Nigeria. It is a south-facing bungalow building with a total area of 2,375 sqft, one front door and one back door, one big living room, five bedrooms, three bathrooms, one kitchen, windows of various sizes, corridors, concrete walls, ceilings, and aluminum roofs. The side view of the house is shown in Figure 1. Using the specific parameters of the house for BEopt thermal modelling and

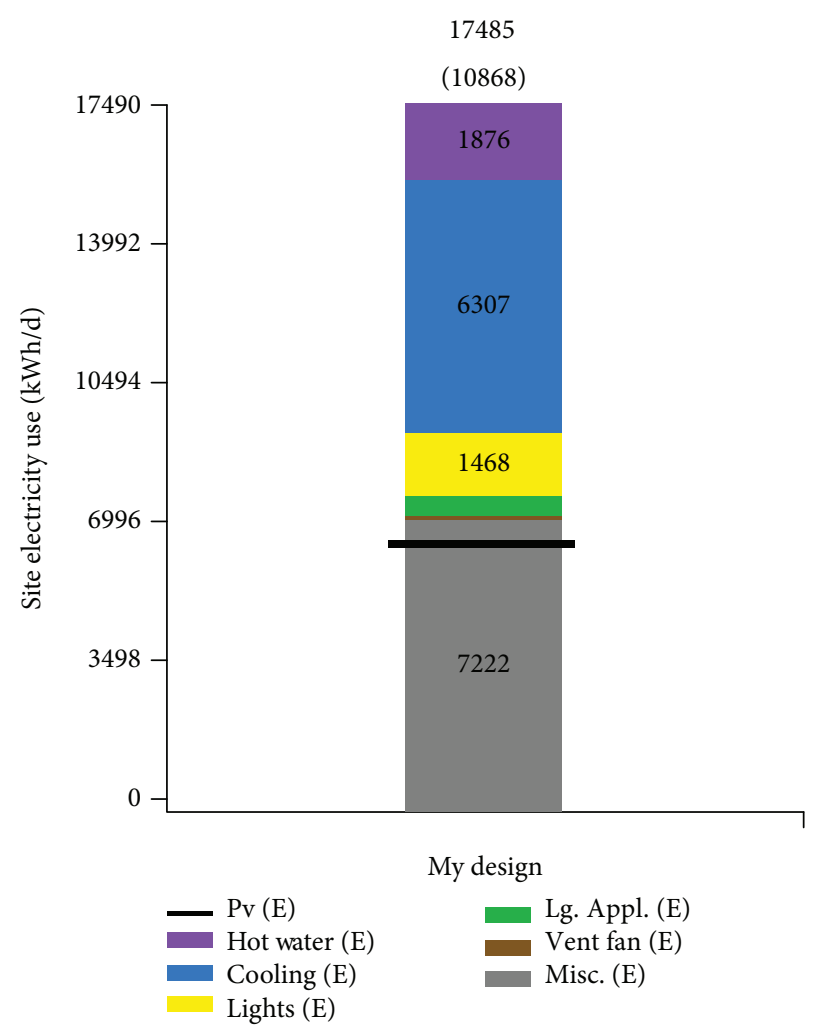

FIGURE 3: House annual energy consumption from BEopt simulation.

simulations (Figure 2), the house was found to require an annual energy consumption of $17,485 \mathrm{kWh} /$ year (about $2 \mathrm{~kW}$ average load) as shown in Figure 3. The generated daily, monthly, and yearly load profiles of the house are shown in Figure 4. However, the PV system component of the hybrid power system is designed for a load of $1.5 \mathrm{~kW}$ with the assumption that the extra refrigerators and heavy air conditioners included in BEopt simulation will be removed before switching to the PV system.

\section{Optimum Hybrid Power System Design with HOMER Pro}

A hybrid power system is made up of various components. In designing a hybrid power system, factors such as the size of the components, system configurations, adequacies of the various renewable energy resources in that region, project economics with changing loads and component costs, life cycle of the system, net present cost of the system, cost of energy to the end user, maintenance costs, and annual operating costs of the hybrid system will help the decision-maker to determine the most cost-effective solutions of the hybrid system to meet the electrical loads for which it is being designed [10]. Hybrid Optimization of Multiple Energy Resources (HOMER) software, developed by the National Renewable Energy Laboratory, models micropower systems with single or multiple power sources (e.g., photovoltaics and wind turbines), and helps to design off-grid and gridconnected systems in the most cost-effective ways by taking the factors above into consideration $[10,11]$. It simulates 


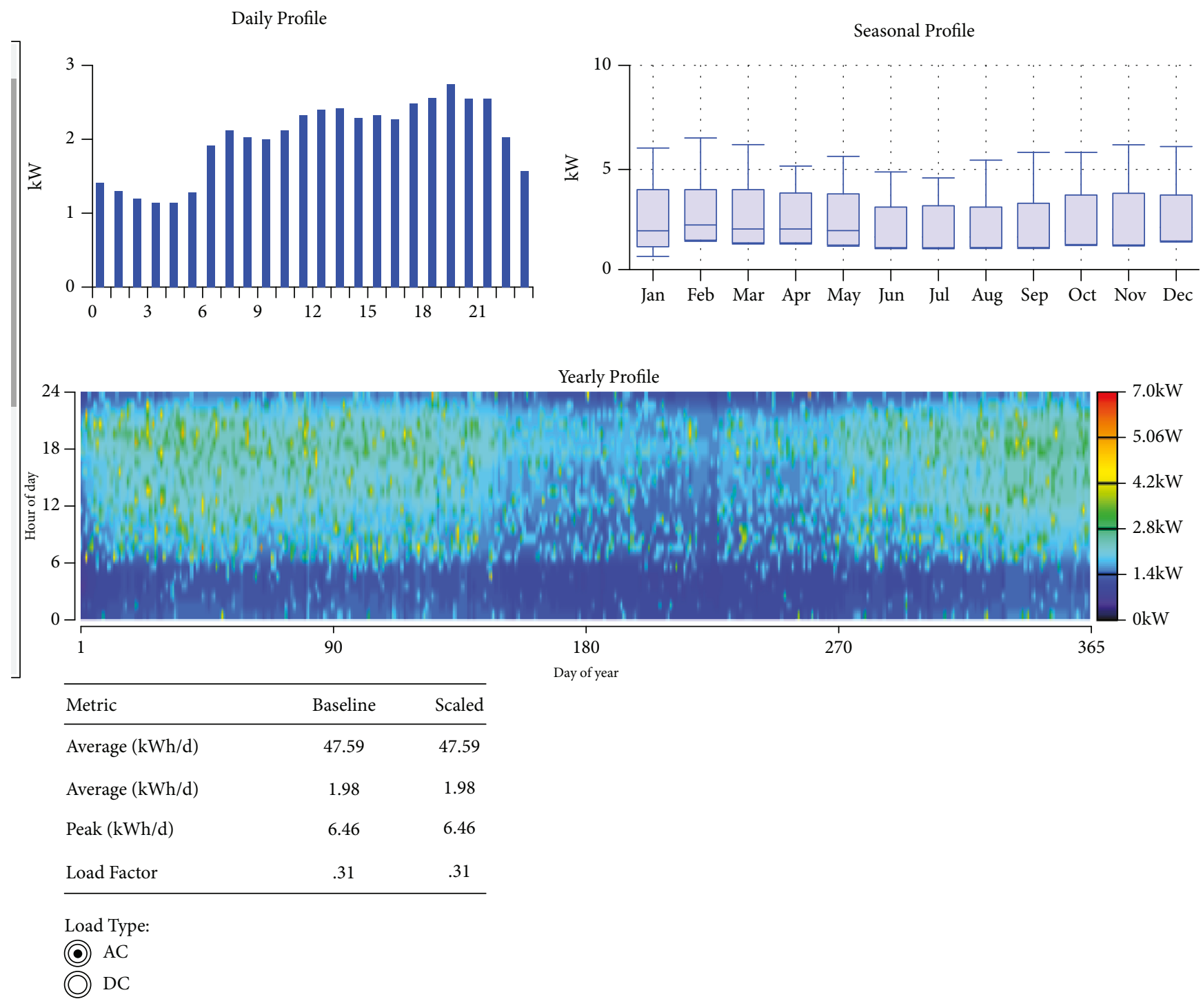

FIGURE 4: Daily, monthly, and annual load profile of the house from BEopt simulation.

various configurations to find the least-cost combinations that meet the electrical loads being considered. HOMER's optimization and sensitivity analysis capabilities help to answer important design questions such as "Which technologies are most cost-effective? What size should components be? What happens to the project's economics if costs or loads change? Is the renewable energy resource adequate?" [11]. From the house thermal model with BEopt software, the generated annual hourly load data (Figure 4) for the house was exported into HOMER Pro software for generator/PV system sizing and optimum hybrid power system design. The simulation was done using the solar irradiation data of the house location (Figure 5), actual PV modules, converters, and batteries, and the optimized hybrid power system configuration is shown in Figure 6. Figure 7 shows a HOMER-optimized hybrid power system design based on the technical and economic data available. Such a system, designed for 25 years life cycle, will have a total net present cost (NPC) of USD 106,307.90, a levelized cost of energy (CoE) of USD 0.4734 per $\mathrm{kWh}$, and an annual operating cost of USD 5,650.04. The system will also have an excess energy of 14.9 percent which can be used to power the bulbs outside the fence of the house. The diesel generator will help to provide backup power during prolonged extreme weather conditions when the primary battery backup power from the PV system is unavailable. The rest of this paper is dedicated to the design and dynamic modelling of the proposed PV system component in the optimal hybrid power system.

\section{The Proposed PV System Components}

The proposed PV system is a stand-alone PV system comprising of PV arrays, DC-DC boost converter, MPPT controller, battery bank, DC-AC converter (inverter), inverter voltage mode controller, single-phase step-up transformer, and the single-phase AC loads of the house under consideration. Figure 8 shows a block diagram of the proposed PV system. 


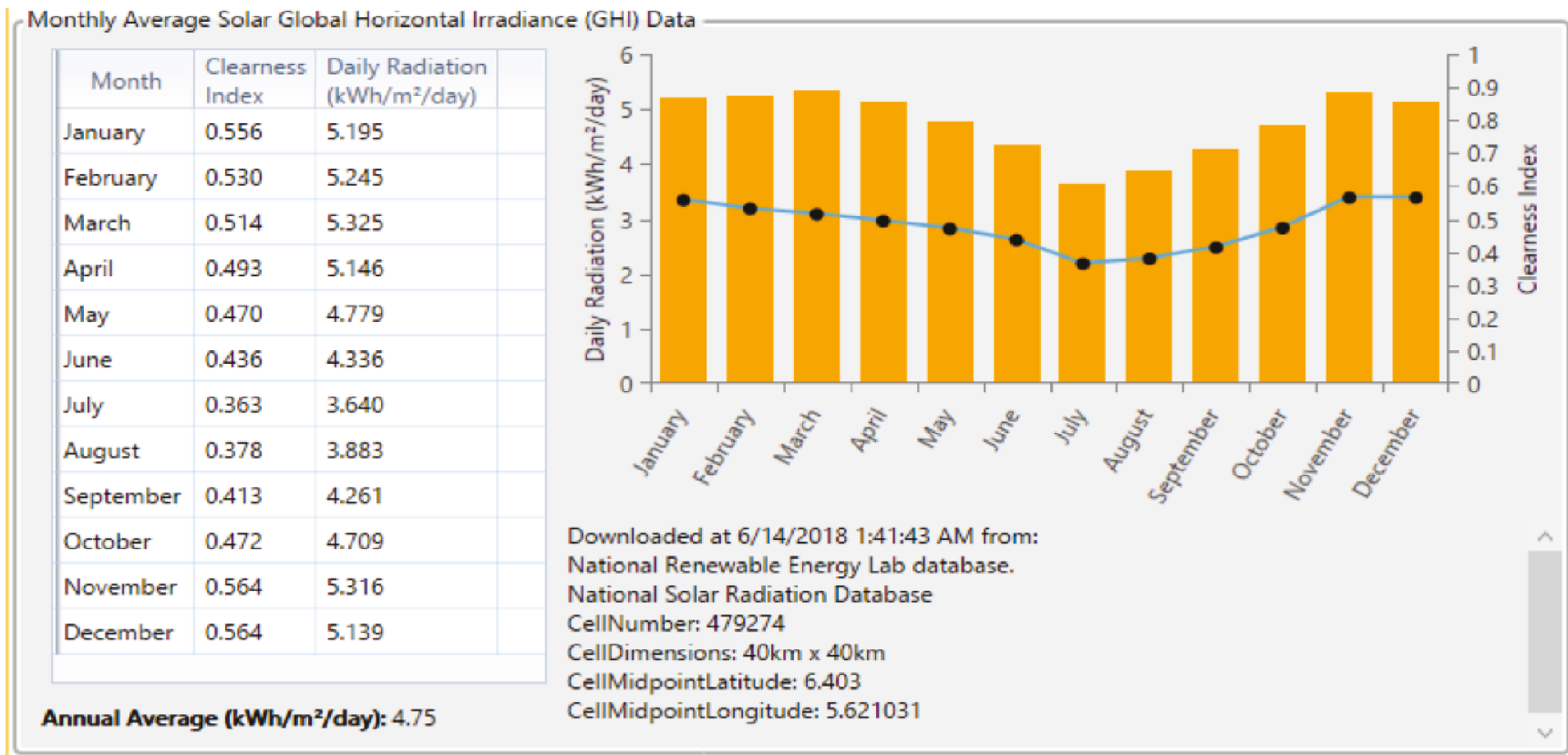

Scaled Annual Average ( $\mathrm{kWh} / \mathrm{m}^{2} / \mathrm{da}, 4.75$

FIGURE 5: Downloaded solar irradiance of the house location.

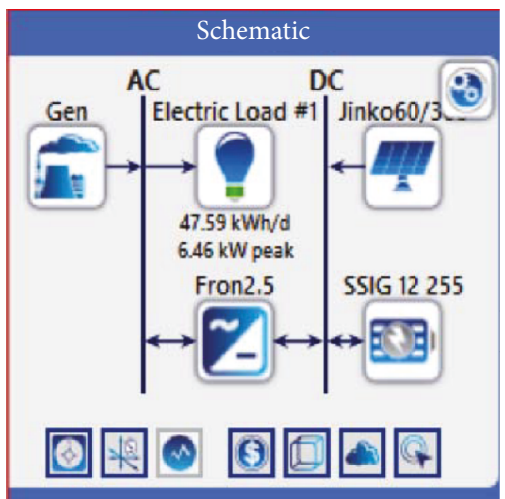

FIGURE 6: HOMER-optimized hybrid power system configuration.

5.1. PV Arrays. Photovoltaics (PV) are used to convert sunlight directly into electricity $[12,13]$. A solar cell is a PN junction diode with current flowing in the reverse direction. A number of solar cells make up PV modules. PV array consists of strings of modules connected in parallel, each string consisting of modules connected in series [13]. Temperature and irradiation level are the two main factors that affect PV array outputs. Change in temperature and irradiation level results in change in voltage and current, as well as power generated by PV systems [14]. Figure 9 shows a solar cell model using a current source IL (light-generated current), diode (I0 and $\mathrm{nI}$ parameters), series resistance $R_{\mathrm{s}}$, and shunt resistance $R_{\text {sh }}$ to represent the irradiance and temperature-dependent $\mathrm{I}-\mathrm{V}$ characteristics [14]. The diode I-V characteristics for a single module are defined by equations (1) and (2) below [14]. The PV array used for this project is the Jinko Solar
JMK300M-72 PV array manufactured by Jinko Solar. The array comprises of 4 strings of 12 panels of PV modules to give an output power of maximum $14.4 \mathrm{~kW}(12 \times 4 \times$ $300=14.4 \mathrm{~kW})$. The I-V and P-V characteristics of the PV array at various temperature and irradiation levels are shown in Figure 10.

$$
\begin{aligned}
I_{d} & =I_{0}\left[\exp \left(\frac{V_{d}}{V_{T}}\right)-1\right], \\
V_{T} & =\frac{K T}{q} \times n l \times N_{\text {cell }},
\end{aligned}
$$

where $I_{d}$ is the diode current (A), $V_{d}$ is the diode voltage $(\mathrm{V}), I_{0}$ is the diode saturation current $(\mathrm{A}), n l$ is the diode ideality factor, a number close to $1.0, K$ is the Boltzman constant $=1.3806 e-23 \mathrm{~J} . \mathrm{K}-1, T$ is the cell temperature $(\mathrm{K})$, and $N_{\text {cell }}$ is the number of cells connected in series in a module.

5.2. DC-DC Boost Converter. The DC-DC boost converter stabilizes and steps up (boosts) the unregulated DC voltage from the PV array to a DC bus voltage output, $48 \mathrm{~V}$, needed to charge the battery. The output voltage of the DC-DC boost converter is fed into the inverter for conversion to AC voltage. The circuit diagram of the DCDC boost converter is shown in Figure 11. From the circuit diagram, the output voltage and current of the DCDC boost converter are given by equations (3) and (4), respectively [15]. From the equations, it can be seen that the output of the converter depends on both the input 


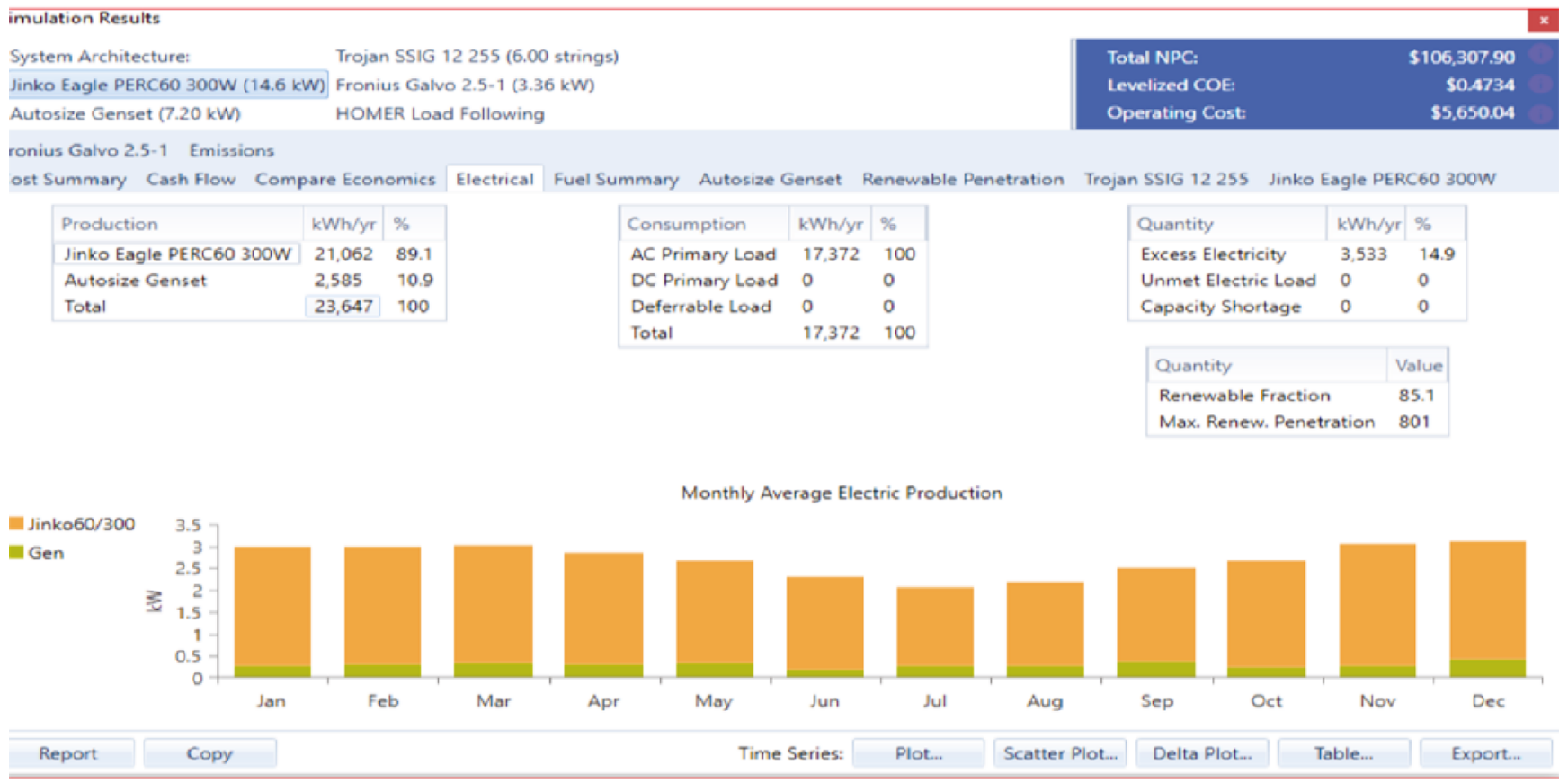

FIGURE 7: HOMER-optimized results and parameters.

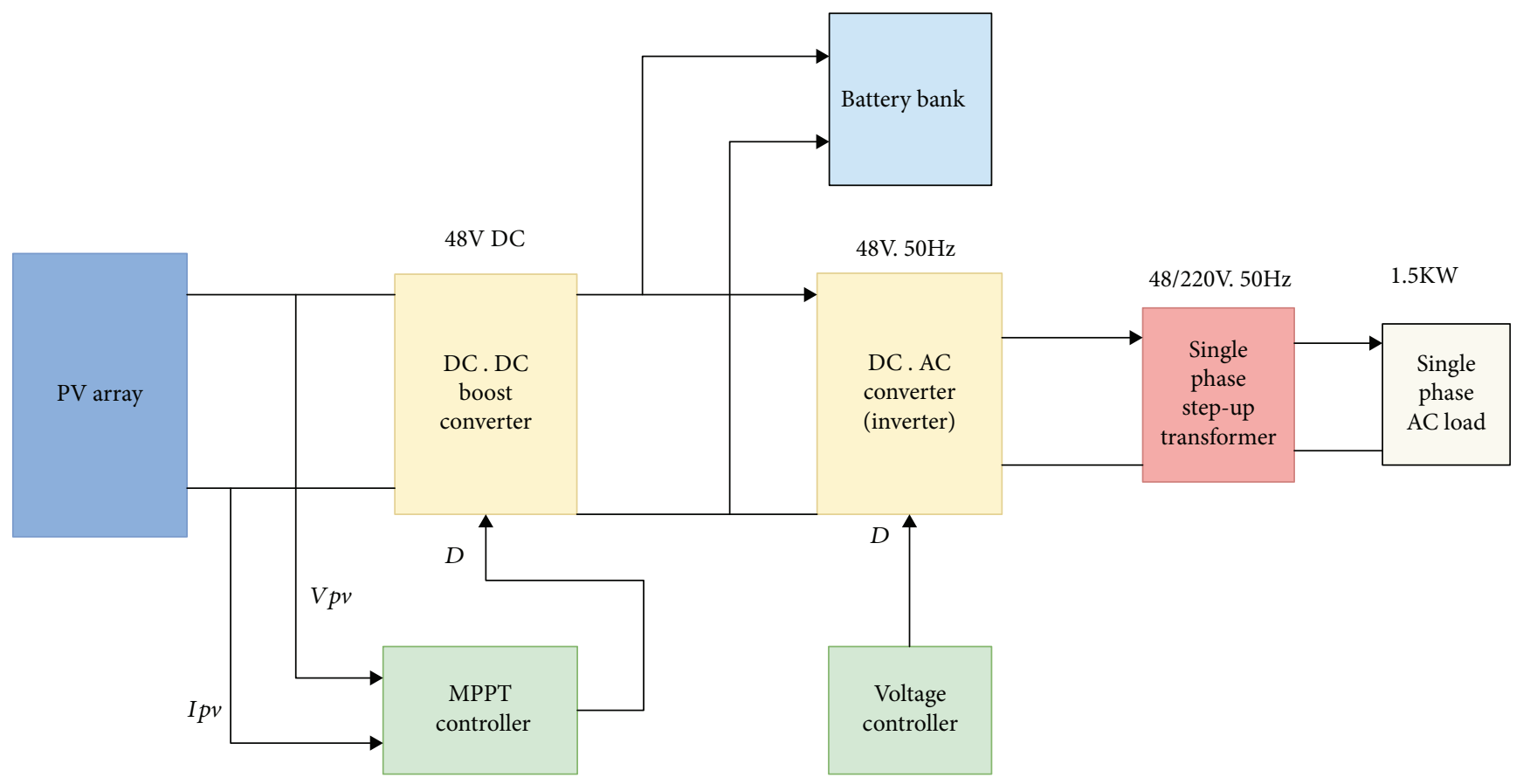

Figure 8: Proposed PV system block diagram.

and the duty cycle, $D$. Therefore, with a fixed input, the output can be controlled by controlling its duty cycle.

$$
\begin{aligned}
& V_{\mathrm{dc} 2}=\frac{1}{(1-D)} \times V_{\mathrm{dc} 1}, \\
& I_{\mathrm{dc} 2}=(1-D) \times I_{\mathrm{dc} 1},
\end{aligned}
$$

where $D$ is the duty cycle of the converter.
5.3. MPPT Controller. At any given time, the point on the I-V curve where the solar module operates is called the operating point (OP) and it corresponds to a given irradiance $(\mathrm{G})$ and temperature $(\mathrm{T})$, which are geographical conditions. Without any external electrical control, the module OP is largely dictated by changes in the line and the load seen by the module at its output [13]. The I-V curve represents the power produced and delivered to the load. Therefore, it is important that the solar module operates at its maximum power point 


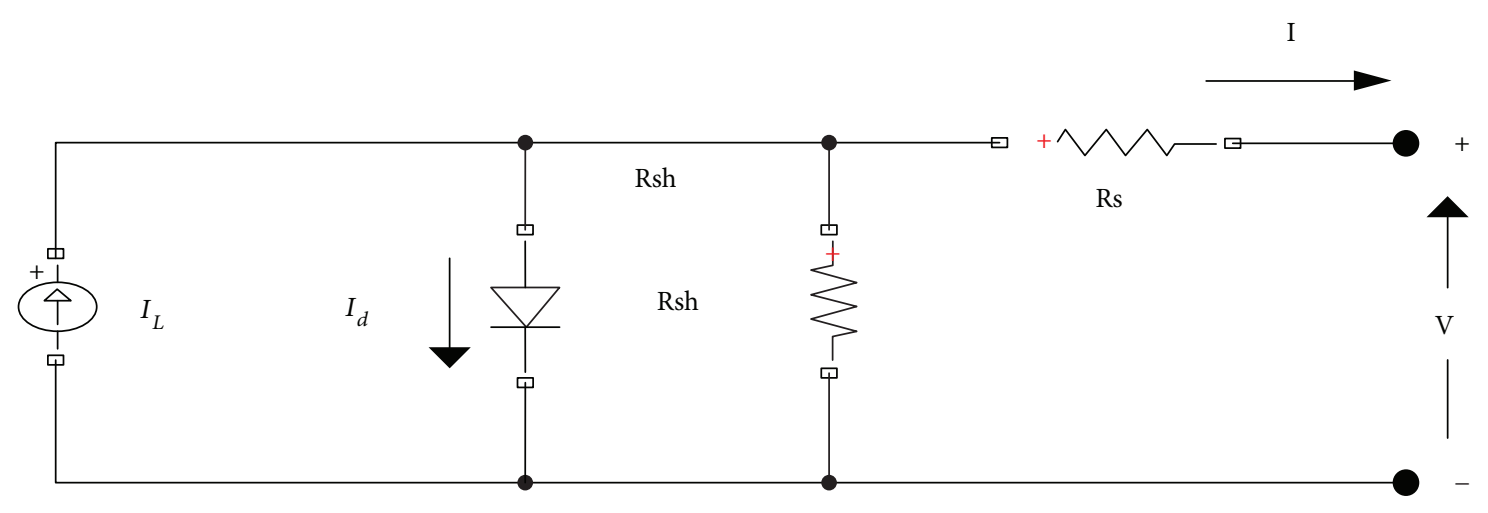

FIGURE 9: Diode model of a PV module.
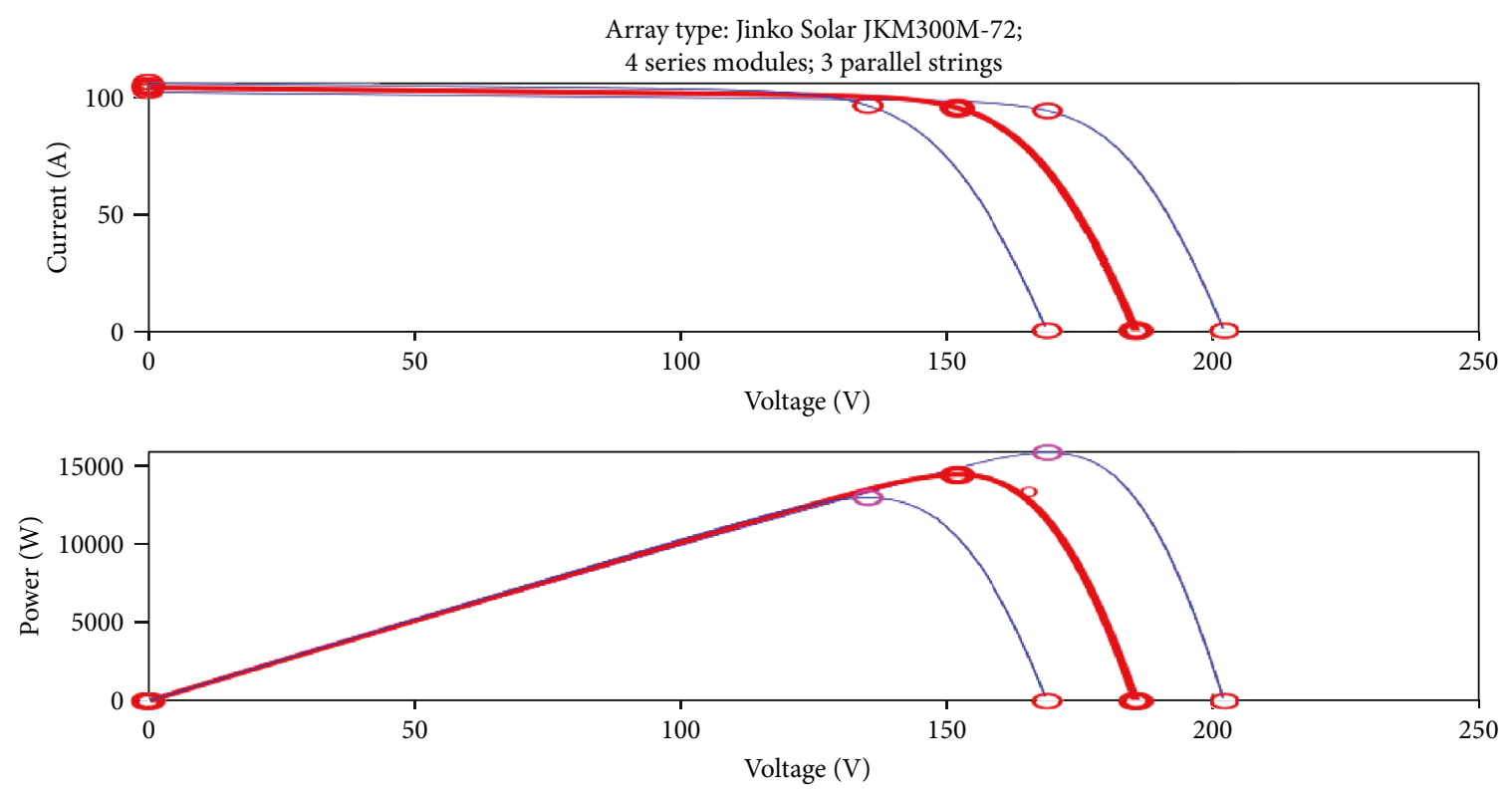

Figure 10: I-V and P-V characteristics of Jinko Solar JMK300M-72 PV array.

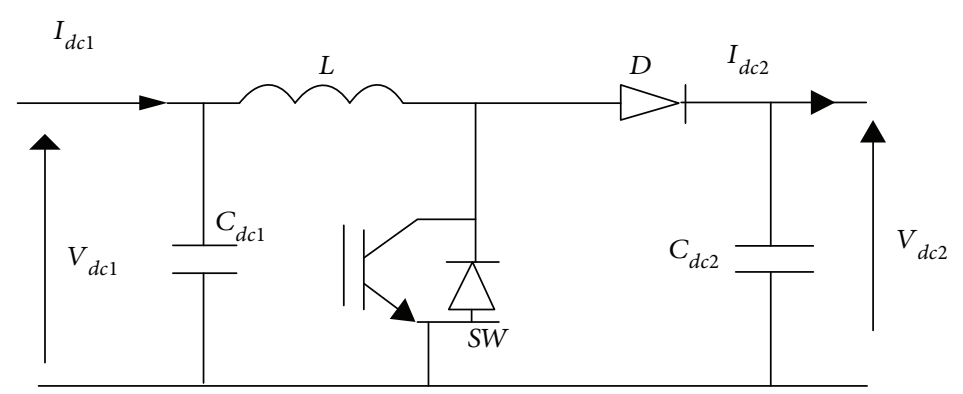

FIGURE 11: DC-DC boost converter circuit diagram.

(MPP). For maximum power output, it is important to force the module to operate at the OP corresponding to maximum power point. With changes in $\mathrm{G}$ and $\mathrm{T}$, the I-V curve changes, which means that the previous MPP (OP) is no longer valid, and a new MPP is created. Thus, to have MPP at all times, changes in the I-V curve have to be tracked to know the new MPP, a process called maximum power point tracking (MPPT). This is achieved using various algorithms. In this paper, the incremental conductance MPPT algorithm is chosen due to its efficiency and accuracy [13]. The voltage and current from the PV array are the inputs of the algorithm, and the generated pulses from the algorithm are used to control the duty cycle, $D$, of the DC-DC boost converter. This algorithm is independent of the solar 
panel characteristics, rather the panel terminal voltage is changed according to its value relative to the maximum power point voltage. Equations (5) and (6) and Figure 12 illustrate the algorithm. Figure 13 shows the flow chart of this algorithm. In this project, the algorithm is implemented using Simulink blocks.

$$
\begin{aligned}
P & =V * I, \\
\frac{d P}{d V} & =\frac{d(I * V)}{d V}=V * \frac{d I}{d V}+I=0,
\end{aligned}
$$

where $P$ is power, $V$ is voltage, $I$ is Current, $d I / d V$ is incremental conductance, and $I / V$ is panel conductance. At $\mathrm{MPPT}, d I / d V=-I / V$ or $d P / d V=0$.

5.4. Battery System. The main purpose of the battery bank is to store extra electrical power generated by the solar PV system and to deliver the stored electrical power to the household electrical loads whenever the PV system is unavailable. The battery system is made up of 24 total batteries ( 6 strings in parallel, each string size being 4 batteries) of the $12 \mathrm{~V}$ Trojan SSIG 12, 255 lead acid battery type. The battery nominal voltage is $48 \mathrm{~V}(12 \mathrm{~V} \times 4)$, the total capacity is $1,542 \mathrm{Ah}(257 \times 6)$, and its autonomy is 29.9 hours which means that the battery system can power the house for almost one and half days if the PV system is out for maintenance or not producing power due to bad weather conditions. The Simulink block model for a lead acid battery is used to model these battery parameters.

5.5. DC-AC Converter (Inverter). An inverter converts a DC input supply voltage into a symmetric AC voltage of desired magnitude and frequency [16]. The single-phase voltage source inverter in this system converts the fixed DC voltage $(48 \mathrm{~V})$ from the DC-DC boost converter into a single-phase AC voltage $(48 \mathrm{~V})$ with a fixed frequency of $50 \mathrm{~Hz}$. In this paper, a single-phase full-bridge inverter with insulated gate bipolar transistors (IGBTs) switches is considered. It consists of four choppers: four switches/gates S1, S2, S3, and S4 and four transistors T1, T2, T3, and T4. With T1 and T2 turned on simultaneously, input voltage appears across the load, while for T3 and T4, voltage is reversed (-Vs). Figure 14 shows a typical full-bridge IGBT-based singlephase inverter [17].

5.6. Inverter Voltage Mode Controller. The inverter output voltage is easily affected by variations in the line and other system parameters [16]. Therefore, there is the need for a proper control scheme to maintain a constant voltage regardless of system disturbance. The voltage mode controller scheme is proposed in this work due to its reliability and ease of implementation [16, 17]. As shown in Figure 15, the DC voltage from the boost converter is sensed and compared with a reference value. The error produced is sent to a PI controller and the PI controller produces an output which is a DC quantity. This DC quantity is multiplied by a sinusoidal value to convert it into an $\mathrm{AC}$ value which is then compared with a triangular waveform to produce pulses for controlling the inverter switches/gates [16].

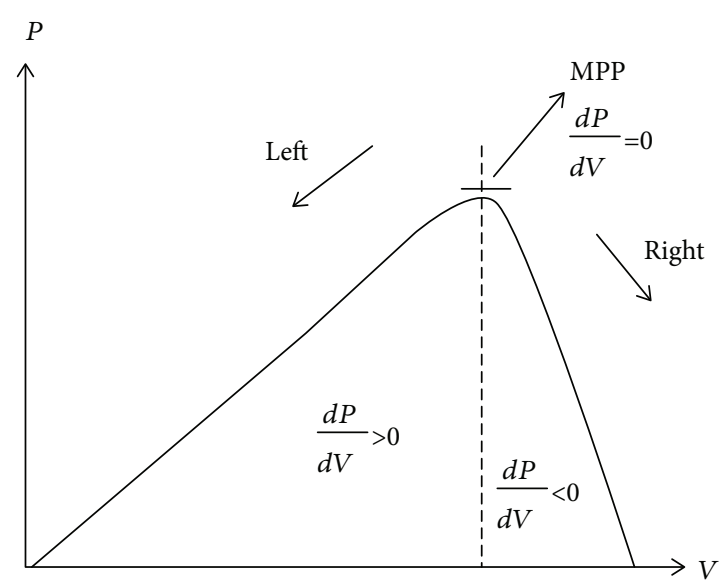

Figure 12: MPPT process.

5.7. Single-Phase Step-Up Transformer. A transformer is an electrical device used to transfer electrical energy from one level to the other at the same frequency by means of a changing magnetic field. It consists of two windings, the primary and secondary windings, separated by a magnetic core. When a transformer is used to "increase" the voltage on its secondary winding with respect to the primary, it is called a step-up transformer and when it is used to "decrease" the voltage on the secondary winding with respect to the primary, it is called a step-down transformer [18]. In this research, a single-phase step-up transformer is used to step up the $48 \mathrm{~V}$ voltage output from the inverter to $220 \mathrm{~V}$ at $50 \mathrm{~Hz}$ to match the household AC loads.

\section{Proposed PV System Dynamic Simulation with MATLAB/Simulink}

Dynamic modelling and simulation is the necessary first step in design, optimization, and performance analysis. In order to study the dynamic behaviors of the PV system component of the proposed hybrid power system with respect to power quality, harmonics, load impact, and voltage transients, the PV system component was simulated in MATLAB/Simulink environment under various conditions specific to the house. The complete MATLAB/Simulink model is shown in Figure 16. Each of the subsystems has been developed using standard equations and calculated and standard parameters from the manufacturers' data sheets.

6.1. Dynamic Simulation Results. The most important dynamic simulation results are shown in Figures 17-22. Figure 18 shows the solar irradiance and temperature on which the PV array is made to operate, as well as the generated power output. Figure 19 shows the current, state of charge (SOC) and voltage $(48 \mathrm{~V})$ of the battery, and from the SOC, it can be seen that the battery is being charged by the PV system for future use. Figure 20 shows the constant DC voltage output $(48 \mathrm{~V})$ of the DC-DC boost converter while Figure 21 shows the generated AC voltage and frequency of the inverter $(48 \mathrm{~V}, 50 \mathrm{~Hz})$ fed to the transformer. The transformer steps this voltage up at the same frequency 


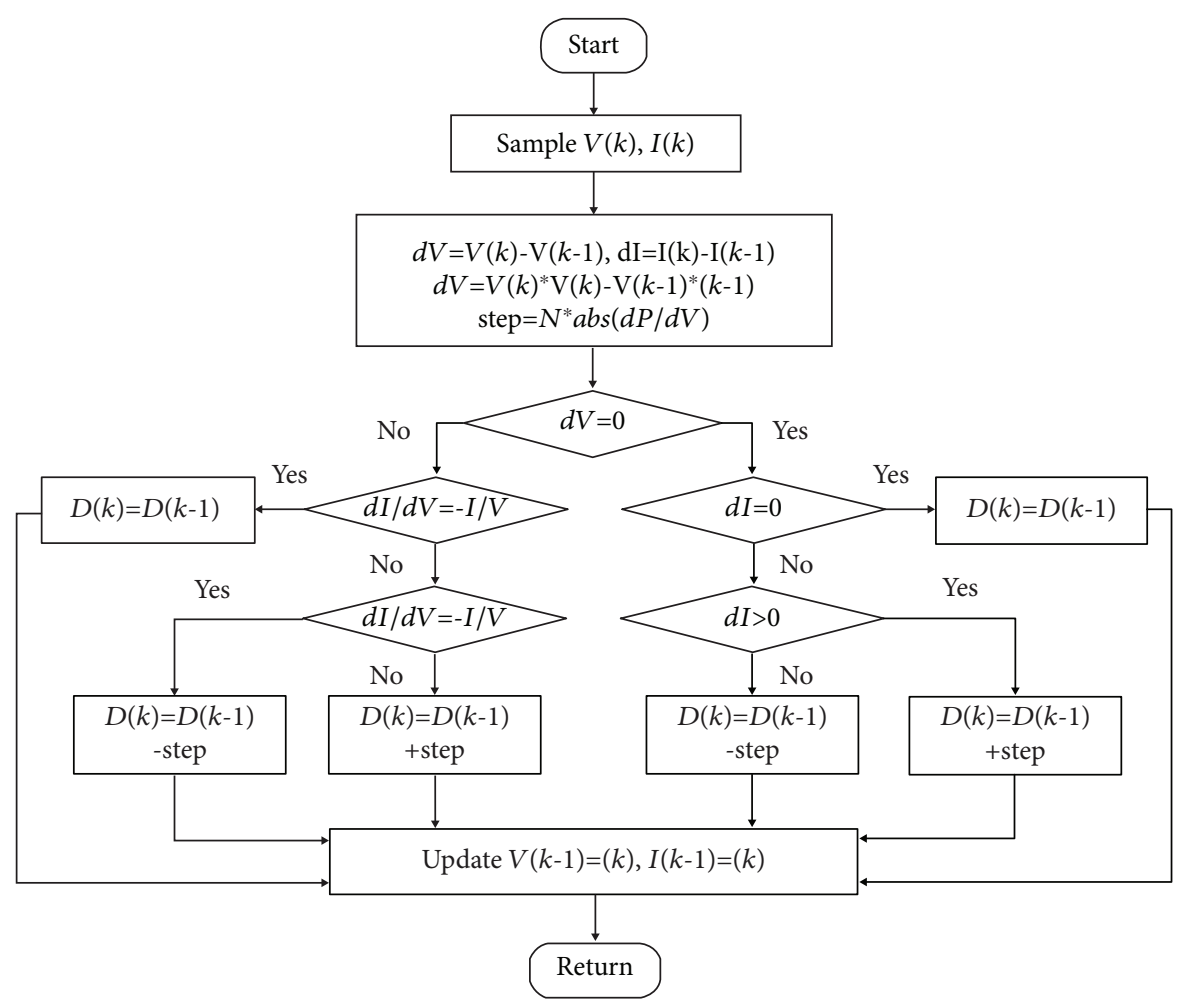

FIGURE 13: Incremental conductance MPPT flow chart.

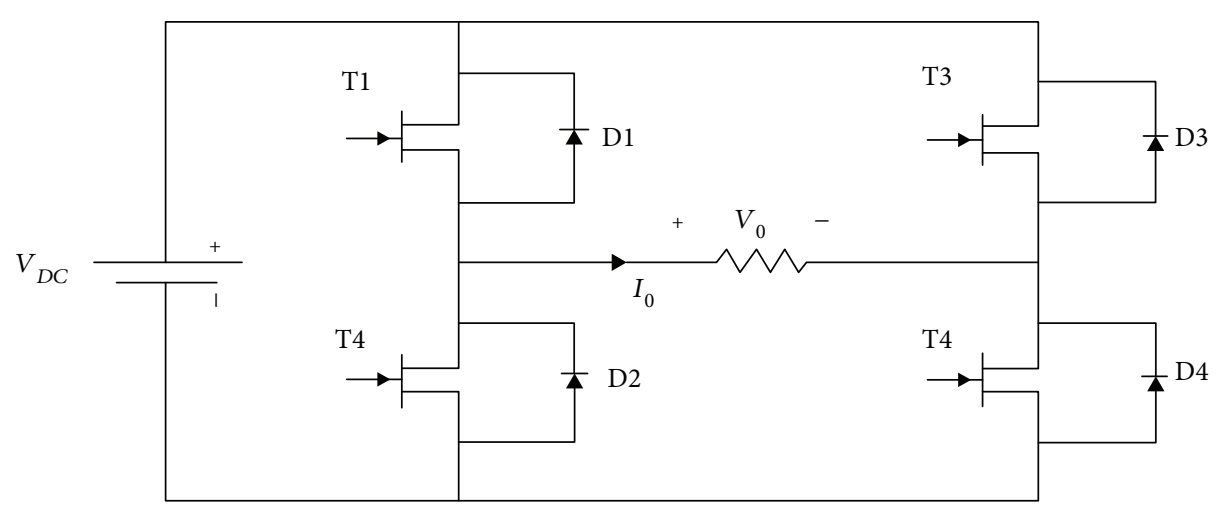

FIGURE 14: The full-bridge IGBT-based single-phase inverter.

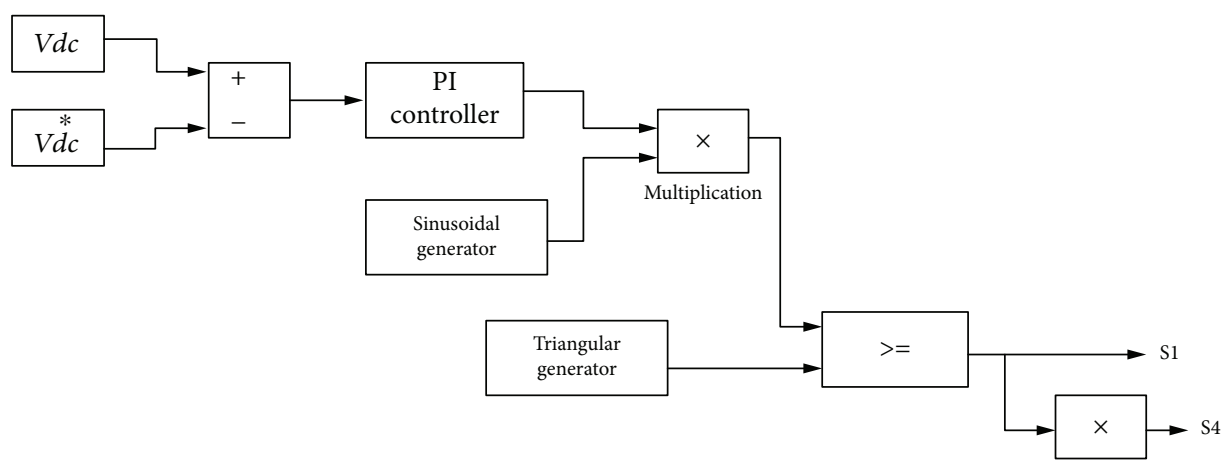

FIGURE 15: Inverter voltage mode controller block. 


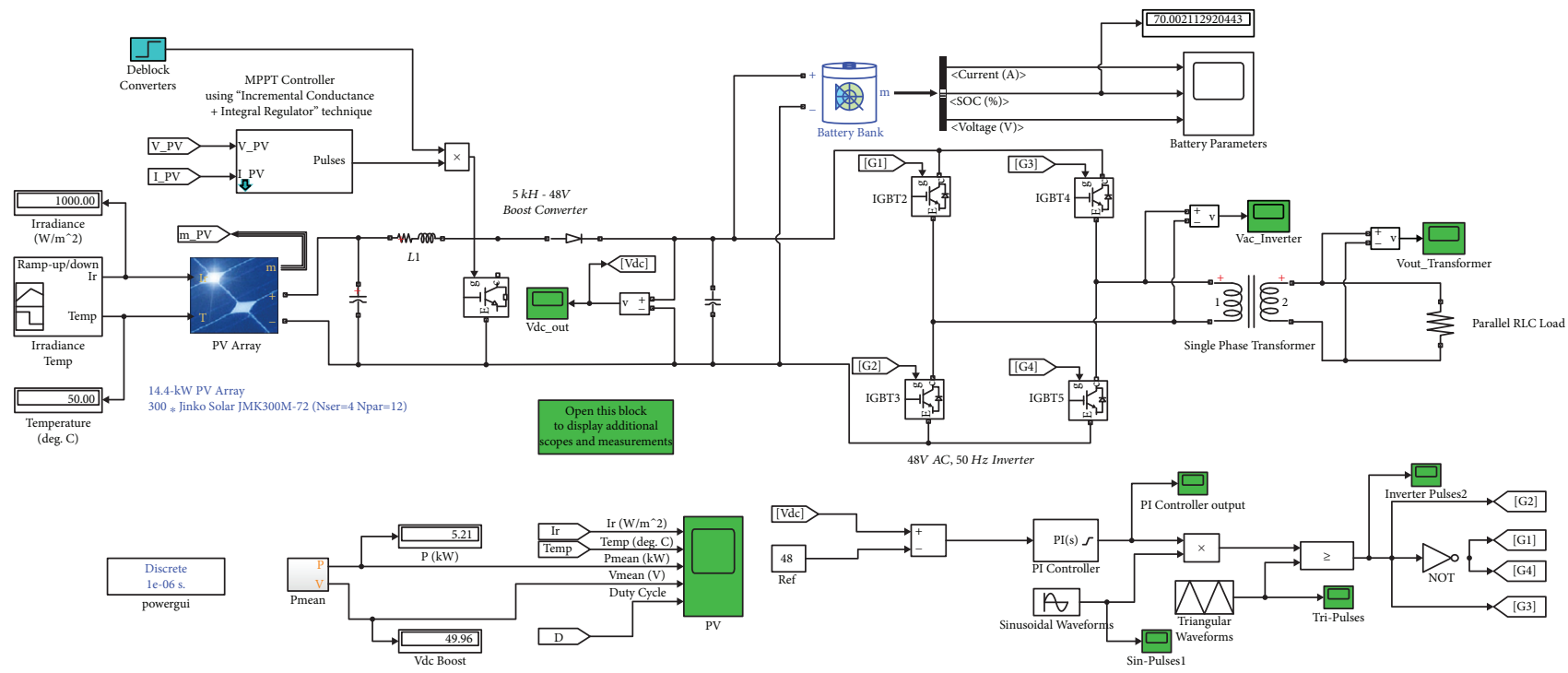

FIGURE 16: MATLAB/Simulink model of the proposed PV system.
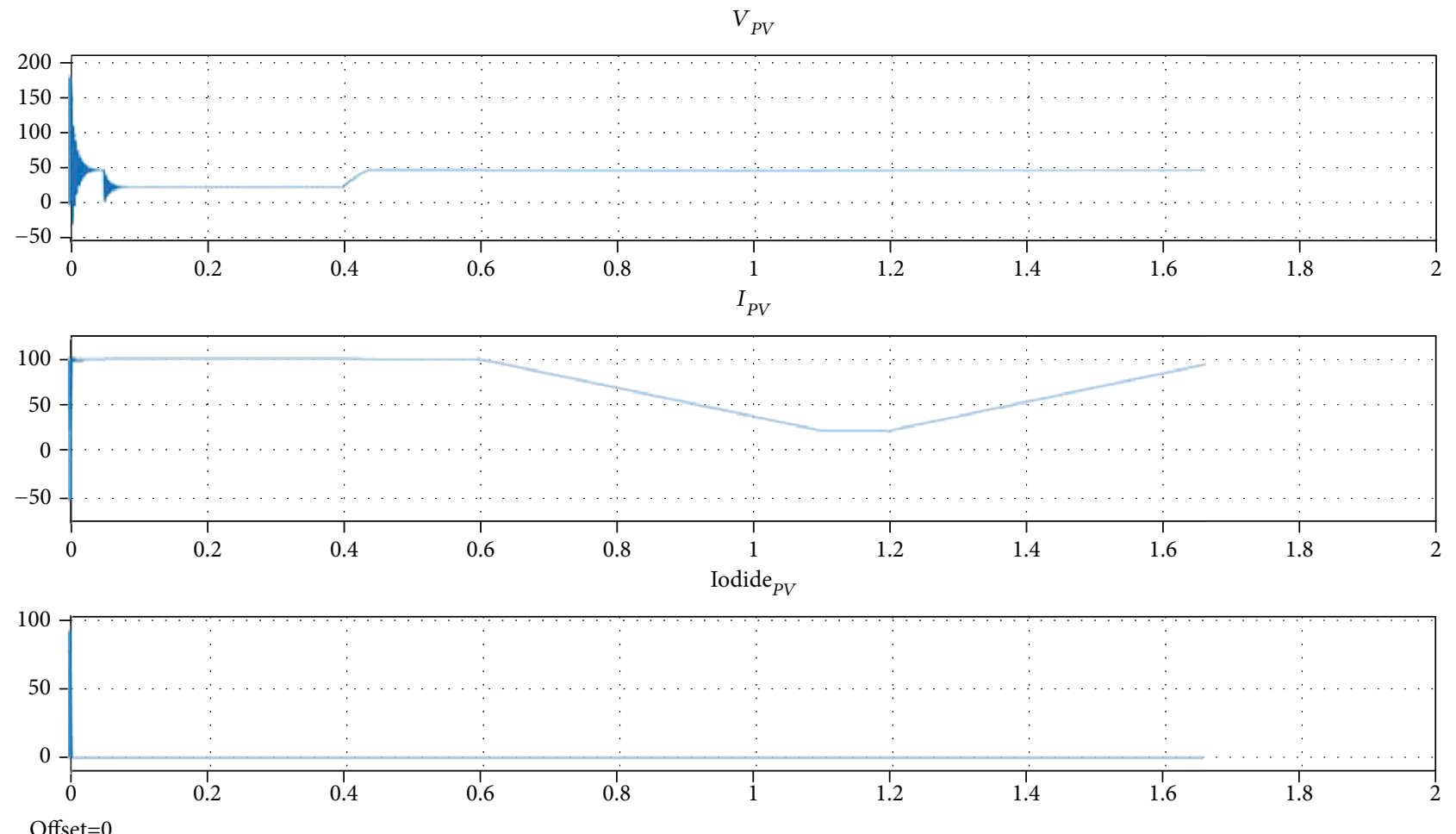

FIGURE 17: PV array voltage and current.

to $220 \mathrm{~V}$ for the household AC loads as shown in Figure 22. All dynamic simulations were done for 3 seconds only.

\section{Future Work}

In the future, battery management system (state of charge controller) can be included and a more sophisticated inverter control scheme (e.g., voltage oriented control, VOC) is recommended for faster response in cases of severe system disturbance such as sudden overload. Also, hardware implementation of the proposed stand-alone PV system is to be carried out for real-life testing.

\section{Conclusions}

In this paper, thermal modelling of a house in Benin City, Edo State, Nigeria, has been carried out with BEopt software, taking into account important parameters such as the type 
$\operatorname{Ir}\left(\mathrm{W} / \mathrm{m}^{\wedge} 2\right)$
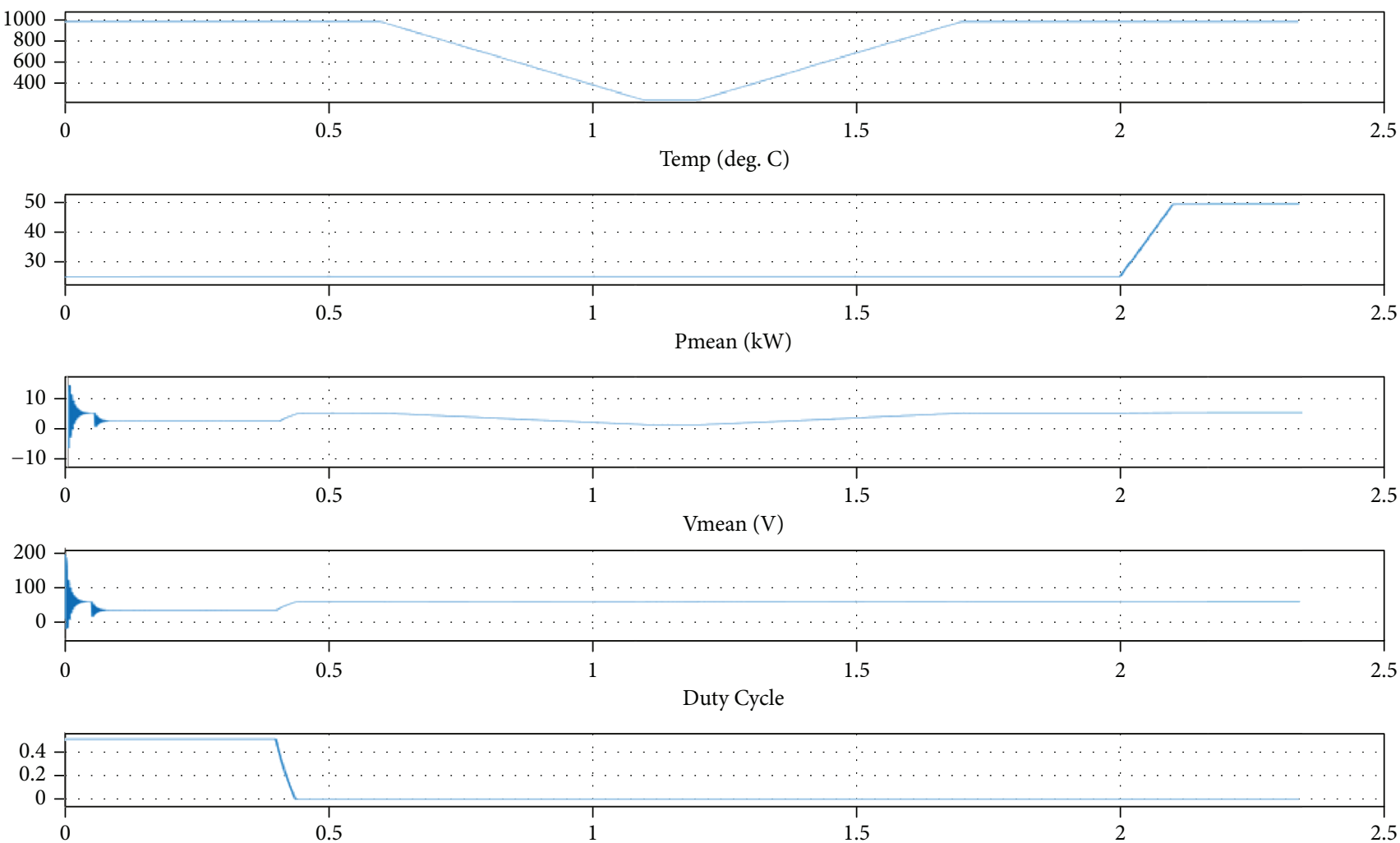

Offset $=0$

FIGURE 18: Solar irradiance, temperature, and generated power.
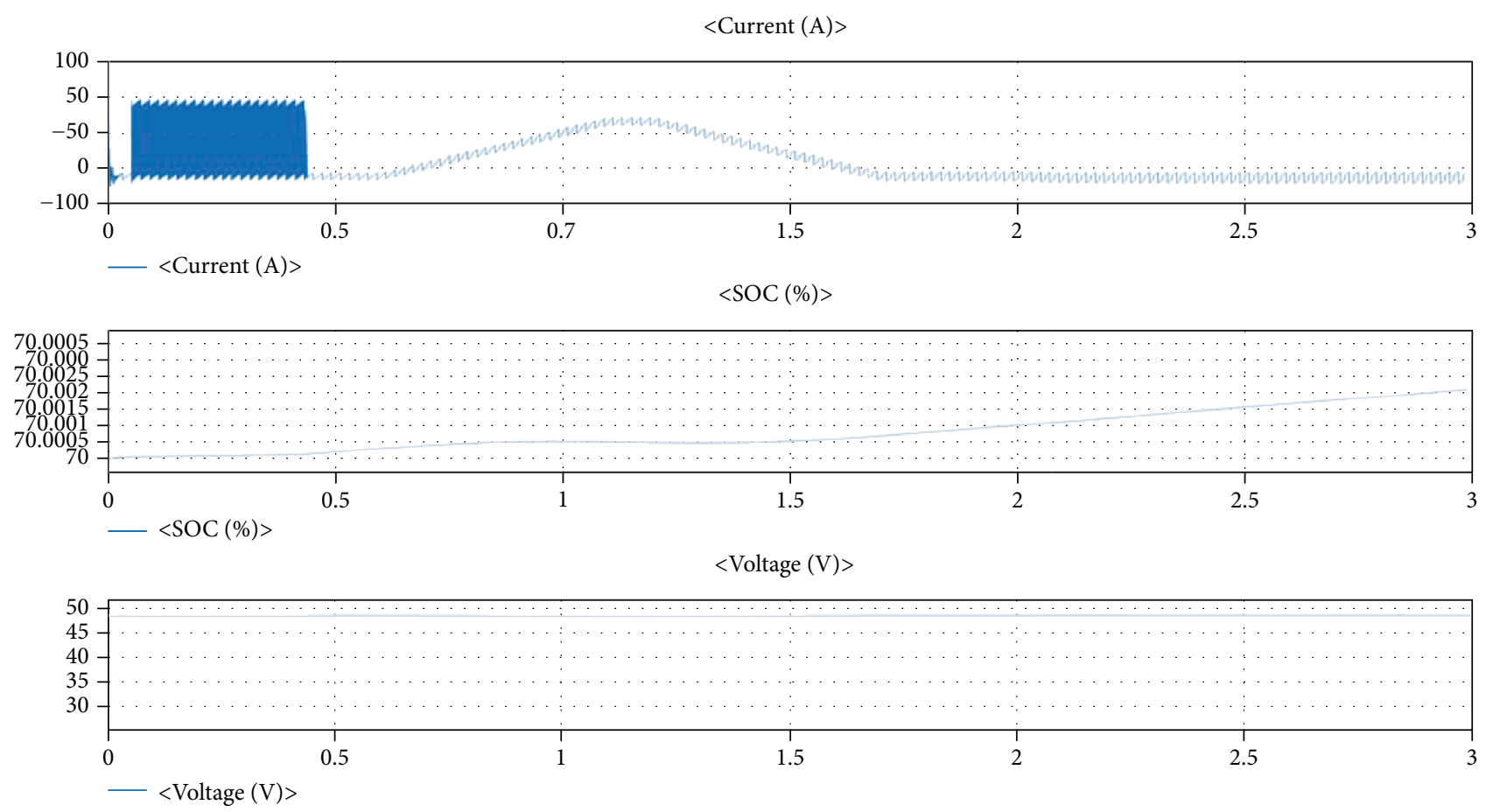

FIGURE 19: Battery current, state of charge, and voltage. 


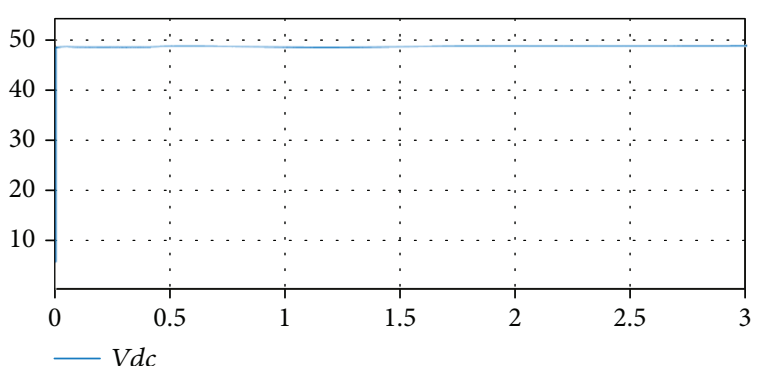

Figure 20: DC-DC boost converter output voltage.

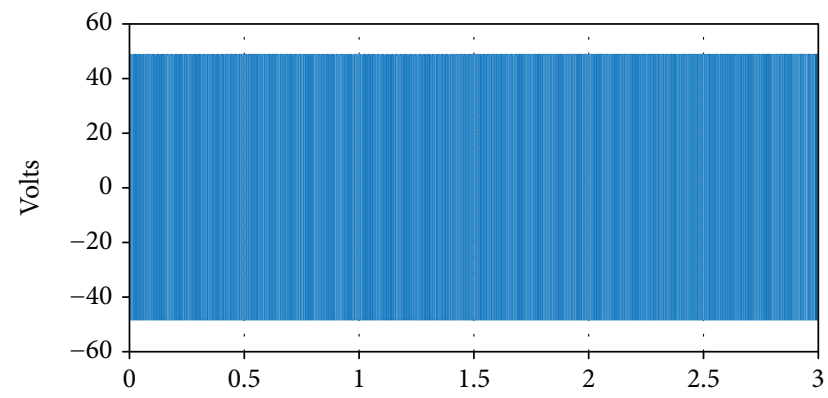

FIgURE 21: Inverter output voltage.

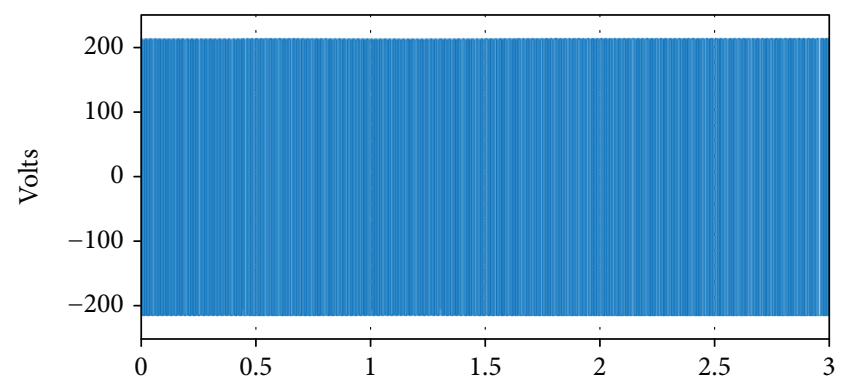

FIGURE 22: Single-phase step-up transformer output voltage/load voltage.

and size of the house, location, and orientation of the house, materials used in building the house, number and types of appliances in the house, and number of occupants. This is because the actual energy needs of a house have been found to be affected by these parameters. Having known the energy needs of the house $(17,485 \mathrm{kWh})$ from BEopt thermal modelling, HOMER Pro software package was used to find an optimum stand-alone hybrid power system solution for the chosen house. To achieve this, the generated annual load profile of the house from BEopt thermal modelling simulation was imported into HOMER Pro software, and through its Add/Remove window, various components of the proposed hybrid power system, such as solar PV arrays, diesel generator, converters, and battery, were selected for simulation. This simulation took into account the project parameters, such as project lifetime, and economic parameters (i.e., costs gotten from the component manufacturers' websites), as well as the available solar irradiance in that region which was downloaded from the National Solar Radiation Database with HOMER resource window. In HOMER Pro, various systems were simulated and technoeconomic analysis was carried out considering factors such as the size of the components, system configurations, adequacies of the various renewable energy resources, project economics with changing loads and component costs, life cycle of the system, net present cost of the system, cost of energy to the end user, maintenance costs, and annual operating costs of the hybrid power system in determining the optimum solution of the hybrid power system to meet the electrical loads of the house. The optimum hybrid power system was found to comprise of a conventional diesel generator and a solar PV system. In order to test the power quality, harmonics, load impact, and voltage transients of the proposed solar PV system component of the hybrid power system, dynamic simulation was carried out in MATLAB/Simulink environment under various system conditions. The simulated results show that the solar PV system is fully capable of powering the house and could serve as a potential solution to the energy crisis in that region.

\section{Data Availability}

The data used to support the findings of this study are available from the corresponding author upon request.

\section{Conflicts of Interest}

The authors declare that there is no conflict of interest regarding the publication of this paper.

\section{Acknowledgments}

The authors would like to thank the School of Graduate Studies, Faculty of Engineering and Applied Science, Memorial University of Newfoundland for providing the conducive environment to carry out this research. The authors would also like to thank the Natural Sciences and Engineering Research Council (NSERC) of Canada Energy Storage Technology Network (NESTNet) for funding this research.

\section{References}

[1] https://en.wikipedia.org/wiki/Nigeria.

[2] https://en.wikipedia.org/wiki/List_of_power_stations_in_ Nigeria.

[3] C. O. Okoye, O. Taylan, and D. K. Baker, "Solar energy potentials in strategically located cities in Nigeria: review, resource assessment and PV system design," Renewable and Sustainable Energy Reviews, vol. 55, no. 2016, pp. 550-566, 2016.

[4] Nigerian Meteorological Agency (NiMet), "Agrometeorological Bulletin No. 10, DEKAD 2 April (11-20) 2018," https:// www.nimet.gov.ng/.

[5] Y.-O. N. Udoakah, E. E. Nta, I. E. Okon, and U. E. Akpabio, "Design of a $1 \mathrm{kva}$ PV system for electrical laboratory in Faculty of Engineering, University of Uyo, Nigeria," in IEEE Global Humanitarian Technology Conference (GHTC 2014), pp. 1-5, San Jose, CA, USA, 2014.

[6] D. O. Akinyele and R. K. Rayudu, "Distributed photovoltaic power generation for energy-poor households: the Nigerian perspective," in 2013 IEEE PES Asia-Pacific Power and Energy 
Engineering Conference (APPEEC), pp. 1-6, Kowloon, Hong Kong, 2013.

[7] M. S. Adaramola, S. S. Paul, and O. M. Oyewola, "Assessment of decentralized hybrid PV solar-diesel power system for applications in northern part of Nigeria," Energy for Sustainable Development, vol. 19, pp. 72-82, 2014.

[8] T. A. Jesha and M. T. Iqbal, "Thermal simulation and energy consumption analysis of two houses in St. John's, Newfoundland," Procedia Engineering, vol. 105, pp. 607-612, 2015.

[9] https://beopt.nrel.gov.

[10] G. Alamri and T. Iqbal, "Sizing of a hybrid power system for a house in Libya," in 2016 IEEE 7th Annual Information Technology, Electronics and Mobile Communication Conference (IEMCON), pp. 1-6, Vancouver, BC, Canada, 2016.

[11] https://www.homerenergy.com.

[12] https://www.pveducation.org/pvcdrom/introduction/solarenergy.

[13] S. Peake, Ed., Renewable Energy: Power for Sustainable Future, Oxford University Press, 4th edition, 2018.

[14] https://www.mathworks.com/help/physmod/sps/powersys/ref/ pvarray.html.

[15] S. S. Mohammed and D. Devaraj, "Simulation and analysis of stand-alone photovoltaic system with boost converter using MATLAB/Simulink," in 2014 International Conference on Circuits, Power and Computing Technologies [ICCPCT-2014], pp. 814-821, Nagercoil, India, 2014.

[16] K. Dubey and M. T. Shah, "Design and simulation of solar PV system," in 2016 International Conference on Automatic Control and Dynamic Optimization Techniques (ICACDOT), pp. 568-573, Pune, India, 2016.

[17] S. M. Cherati, N. A. Azli, S. M. Ayob, and A. Mortezaei, "Design of a current mode PI controller for a single-phase PWM inverter," in 2011 IEEE Applied Power Electronics Colloquium (IAPEC), pp. 180-184, Johor Bahru, Malaysia, 2011.

[18] https://www.electronics-tutorials.ws/transformer/transformerbasics.html. 

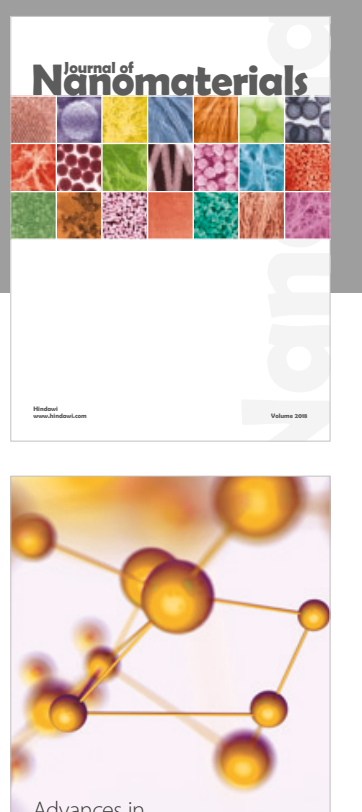

Physical Chemistry
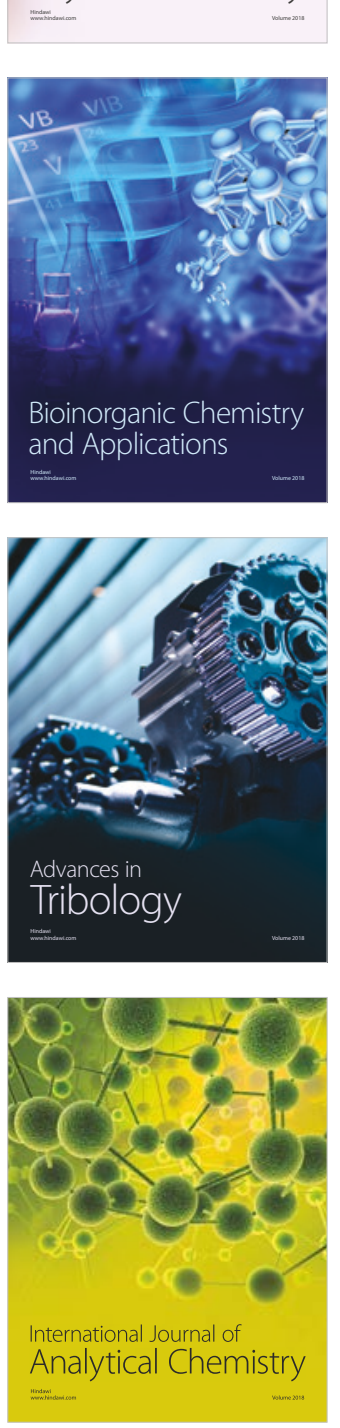

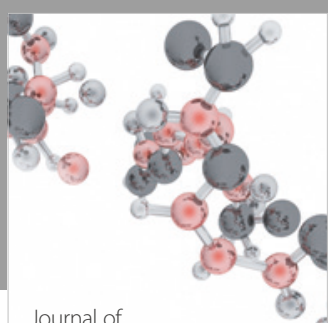

Analytical Methods

in Chemistry

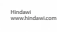

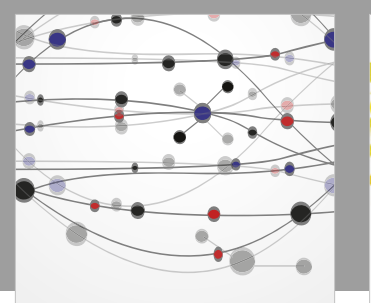

The Scientific World Journal

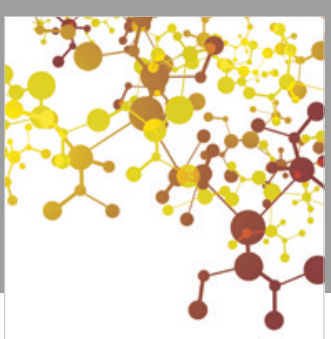

Journal of

Applied Chemistry
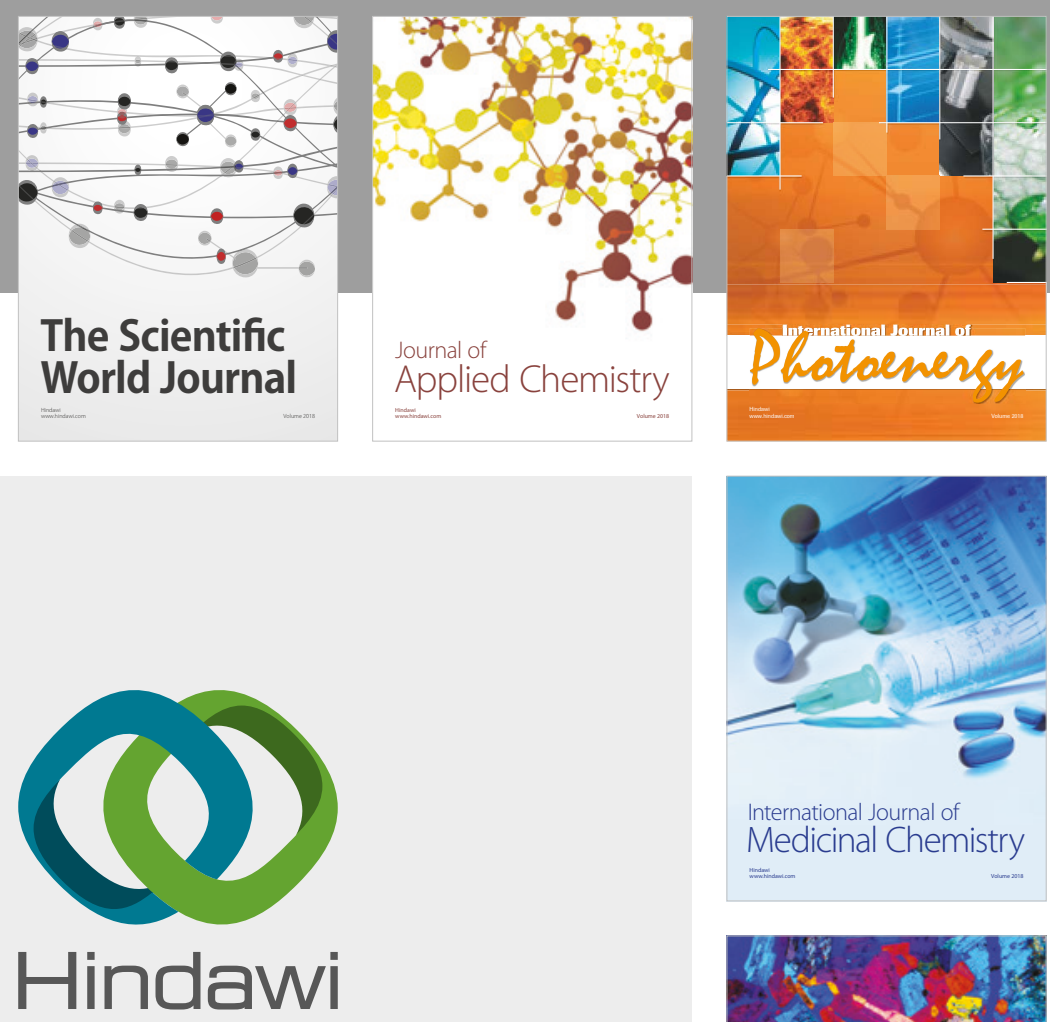

Submit your manuscripts at

www.hindawi.com
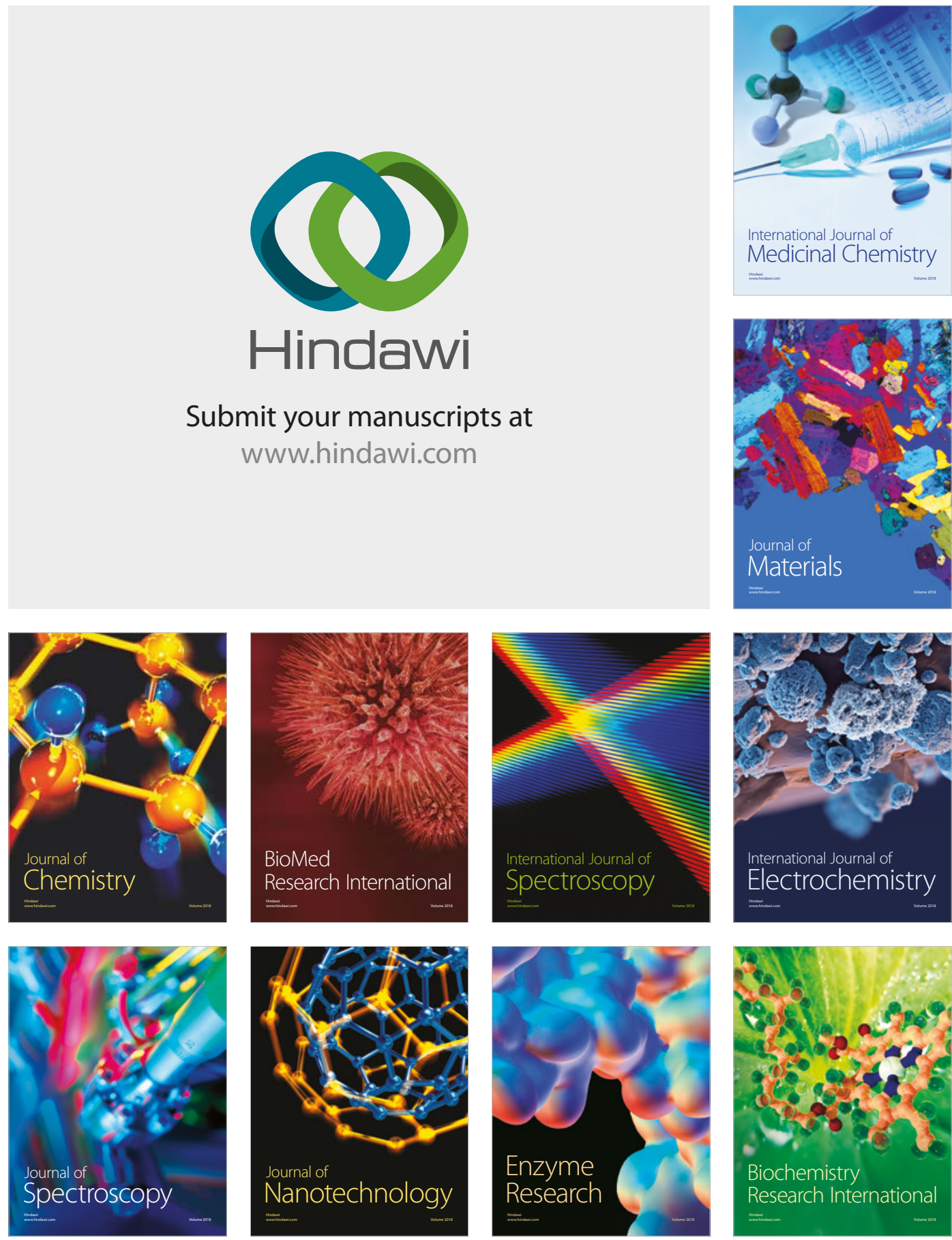
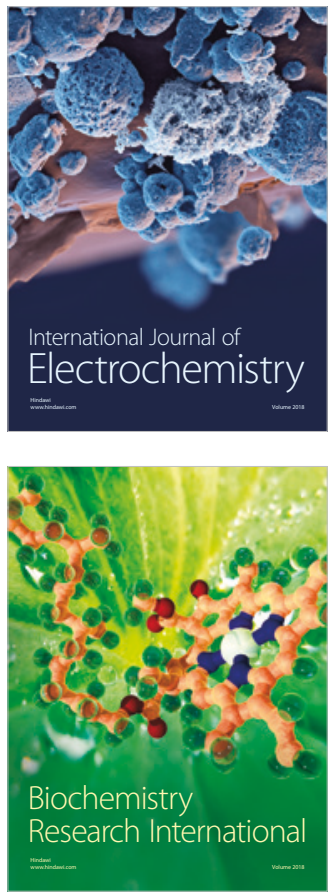